\title{
Examples of industrial and military technology transfer in the eighteenth century
}

Des exemples de transferts techniques industriels et militaires au dix-huitième siècle

\section{Margaret Bradley}

\section{OpenEdition Journals}

Édition électronique

URL : http://journals.openedition.org/dht/1340

ISSN : 1775-4194

Éditeur :

Centre d'histoire des techniques et de l'environnement du Cnam (CDHTE-Cnam), Société des élèves du CDHTE-Cnam

Édition imprimée

Date de publication : 1 décembre 2010

Pagination : 87-95

ISBN : 978-2-9530779-5-7

ISSN : $0417-8726$

Référence électronique

Margaret Bradley, " Examples of industrial and military technology transfer in the eighteenth century », Documents pour l'histoire des techniques [En ligne], 19 | $2^{\mathrm{e}}$ semestre 2010, mis en ligne le 21 juin 2011, consulté le 07 septembre 2020. URL : http://journals.openedition.org/dht/1340 


\title{
Examples of industrial and military technology transfer in the eighteenth century
}

\author{
Margaret Bradley
}

arge-scale industrial development occurred in LBitain much earlier than on the Continent of Europe. The age of the machine needed capital, raw materials, labour and, of course, markets. Britain profited during the eighteenth century from her overseas trade, particularly with her colonies. Owners of great estates had money to invest in mining and industry. Britain also had resources of coal and iron-ore (although, for steel-making, it was necessary to import the appropriate iron from Sweden) within viable distance of ports, and an efficient merchant navy provided the means of trading in foreign markets. For woollen and leather goods, the raw materials were produced locally on farms.

The Continent also had coal, iron, timber, wool and other such raw materials and it must be said that technical knowledge there, was, in some areas, more highly developed than in Britain in the second half of the eighteenth century. However, progress was delayed by wars and civil unrest and there was considerably less available capital. France's progress was hampered by a shortage of coal and other essential raw materials, in addition to restrictive guilds, heavy taxation and bureaucratic limits on commerce and navigation. There was also an over-concentration on the production of luxury goods.

\section{Industrial espionage and technological transfer}

So began the long tradition of industrial espionage through the eighteenth and nineteenth centuries as a way of transferring Britain's technological prowess to the New World and Europe. The British authorities did everything they could to protect their secrets but in no time at all they started to filter across the Channel. In fact, the eighteenth century was a time of large-scale industrial espionage on the part of all interested western countries. An American industrialist commented on
Britain's treasure-house of industrial secrets in the 1820s: "The knowledge of the useful arts, now cultivated as a branch of public instruction, is not infrequently to be gained either by entering apartments filled with the smoke of furnaces, and resounding with the deafening noise of machinery, or by conversing with men devoted to the common handicraft labors of life". ${ }^{1}$

Many Frenchmen came to Britain and their visits were not always clandestine. Bosc d'Antic, for instance, a specialist in glass production, came to England from the French Académie des sciences to study British methods. In 1771, he reported to the Académie on his visit, calling for support for the French glass industry so that it could compete with Britain. Some came simply out of interest and curiosity but, for the most part, the aim was to rival Britain in industry and production. Visitors came on behalf of their own companies as skilled craftsmen, aiming to expand their trade and to acquaint themselves with technological innovations.

France was deeply involved in espionage, and a very effective means of accomplishing the acquisition of expertise was through the recruitment of foreign workers and experts. In 1752, Trudaine de Montigny ${ }^{2}$ commented "the arts never pass by writing from one country to another, eye and practice can alone train men in these activities". ${ }^{3}$ Birmingham, with its thriving

1 Zachariah Allen, The practical tourist, 2 vols., Providence RI, 1832, 1, pp. 5-6.

2 Son of Daniel Trudaine (1703-1769) who, in 1744 created a design office in Paris which, in 1747, was to become a school, the prestigious civil engineering École des Ponts et Chaussées (Margaret Bradley, A career biography of Gaspard Clair François Marie Riche de Prony, Bridge-builder, Educator and Scientist, Lampeter and New York, 1998, p. 38). His son, Jean-Charles Trudaine de Montigny (1733-1777), a chemist of some distinction, succeeded his father on his death as "intendant des finances". Among the responsibilities of their administration was the service of the "ponts et chaussées".

3 Paul Boissonnade, "Trois mémoires relatifs à l'amélioration des 


\section{Examples of industrial and military technology transfer in the eighteenth century}

hardware production was a particular target for the French. Moreover, despite prohibitions, English products flowed into France. The actual transfer of the means of production was subject to all sorts of conditions, not least the quality, quantity and availability of the raw materials. One of the reasons for French failure in steel production was their reluctance to use Swedish iron for conversion, as the English did, and described by Ballot: "The French government, during the second half of the eighteenth century pursued with the most remarkable efforts the importation of this industry into France", ${ }^{4}$ with reference to Birmingham's mechanical and metallurgical expertise.

Michael Alcock was one manufacturer with a large factory producing metal goods who went to France. On arrival, probably at Saint-Omer, somewhere between 1755 and 1756, he quickly made his talents known.

“He was able to make gilt, silver-plated and lacquered alloy buttons, and the newly fashionable ones encrusted with polished steel, buttons and buckles wholly of steel, mechanically cut files made with his new machine, and Staffordshire earthenware decorated by a new system". 5

Another important reason for the rivalry with Britain was armaments. The interest in British methods of iron production was particularly stimulated by the visit to Britain of the young Gabriel Jars in 1765 . Sent by the French government as an industrial spy to investigate English methods of iron-metallurgy, steel making was one of his priorities, as well as the methods of polishing steel goods and cutting and tempering files. ${ }^{6}$ While the French Revolution limited technological transfer, France had had considerable access to English technology in the previous thirty years through the movements of Jars, Wilkinson, and many others. ${ }^{7}$ Jars included a careful description of a Newcomen pump seen in Newcastle. He looked at cementation steel-making both in the North East and in Sheffield, where he also investigated cast steel production. He examined as much as possible and he particularly recognised the value of coke and the

manufactures de France sous l'administration des Trudaine", Revue d'histoire économique et sociale, 7, 1914, no. 1, p. 5686, cf. p. 68.

4 Charles Ballot, L'introduction du machinisme dans l'industrie française, Paris-Lille, O. Marquant, 1923, p. 8.

5 John R. Harris "Michael Alcock and the transfer of Birmingham technology to France before the Revolution", Journal of Economic History, 15, 1, 1986, pp. 7-57, cf. p. 11

6 Archives nationales (Paris) [hereafter AN]: F/12/1311

7 Denis Woronoff, L'industrie sidérurgique en France pendant la Révolution et l'Empire, Paris, 1984, pp. 315-331 importance of its quality. After his return to France, he experimented with coke-making and coke-smelting and identified the Mont-Cenis-Le Creusot area as one where the availability of coking coal would allow the use of coal in iron-making. Experiments there were unsuccessful and Jars's death in 1769 put an end to them. The search was now left to others and, for example, de la Houlière, a young artillery officer, visited Britain in 1775 to see the Wilkinson brothers.

It therefore sometimes happened that an English industrialist willingly co-operated with a French counterpart and in 1781, John Wilkinson, an iron-master in the vanguard of technology, collaborated with the French iron-master Wendel in erecting at Le Creusot (Burgundy), updated iron-works designed on the English pattern, and equipped with blast-furnaces producing coke-containing cast iron. Wendel, from a long line of forge-masters, confessed himself unable to build a coke-burning furnace. It was said of him, "there is in France but one man capable of doing so and he has had to have recourse to the English technical expert Wilkinson", who was also indispensable for the essential steam engines. ${ }^{8}$

In spite of all their efforts, the French failed to produce good steel. In 1788, just prior to the Revolution, it was stated by the Bureau of Commerce that "among existing manufacturers, those established to produce steel and those concerned with spinning have been the main objects of our attention. As for steels, the prejudice still exists that they cannot be made in France as they are in England, or even Germany and, in practice, we must concede that until this time, we have not succeeded in making cast steel ... for this, we have been constantly dependent on England". ${ }^{9}$

Another example of technology transfer is that of the copper sheathing of ships. The nineteenth century innovation of iron ships eclipsed its significance, but in the building of Bellerophon, the ship to which Napoleon surrendered after Waterloo, "2,700 rectangular copper sheets were nailed over her planking with copper nails in order to discourage barnacles and teredo worms" ${ }^{10}$ It has been estimated that 11 tons of copper were used on a typical ship. Nelson's Victory, launched in 1765, whose first timbers were laid in 1759, was copper-sheathed, and saw active duty until $1812 .{ }^{11}$

\section{AN: $F / 14 / 7866$}

9 AN: F/12/107/1

10 D. Cordingly, Billy Ruffian: the Bellerophon and the Downfall of Napoleon, London, 2004, pp. 40-41 ; John R. Harris, "Copper and shipping in the eighteenth century", Economic history review, 19 3, 1966, pp. 550-568.

11 A. McGowan, HMS Victory, her construction, career and restoration, London 1999, p. 7 
In spite of many attempts to increase the protection of the ship's timbers, complaints were still made that the worm continued to make "very destructive ravages upon the bottoms of ships, especially those employed in the West Indies". ${ }^{12}$ Lescallier and Forfait were to interest themselves in copper when they visited England. ${ }^{13}$ The copper improved the handling characteristics of ships, greatly decreased their maintenance time and cost and was particularly valuable in parts of the world where shipworms flourished. Introduced by the British navy in 1761, the use of copper was soon copied by other European navies. The French chemist Hassenfratz ${ }^{14}$ visited England and Ireland in 1790, on behalf of the French navy. He went to Birmingham to see the workshops and to investigate the price of copper. ${ }^{15}$

However, copper sheathing combined with iron bolts on the ship's bottom and the pintles of the rudder, produced severe oxidation and in fact, destruction. In 1783, the navy board contemplated the discontinuance of the sheathing, but "it was directed that mixed metal bolts should be used in 44 gun ships ... and then, in the same year, copper bolts were ordered for all classes of ship ... less oxidizable metal, used as fastening of the ship, would remain good, notwithstanding the copper sheathing ... if the copper sheathing were more oxidizable than another metal with which it might be connected in the bottom of the ship, the sheathing would be the first to yield to the corrosive action". ${ }^{16}$ Galvanic action between the copper sheathing and the iron bolts securing the ship's timbers eroded the bolts, so that the practice almost came to a halt. With the solution of the use of copper bolts there was a rapid resumption of coppering by the Royal Navy from August 1783 and the news carried swiftly to France. In 1784, Wendel and De Givry went to Britain to see, not only the advances in iron production but in copper sheathing, visiting the great smelter at Ravenhead in Lancashire recently built by the Williams group, and also the extensive water-powered works at Holywell in North Wales where the bolts were made. ${ }^{17}$ There seem to have been no qualms about selling their naval technology in peacetime. Matthew Boulton described the traffic in bolts and sheathing "to all the naval powers of Europe";

12 John Finnan, History of naval architecture, London, 1851, p. 95. 13 Margaret Bradley, Daniel Lescallier, 1743-1822, Man of the sea - and military spy?, Lampeter and New York, 2005.

14 J.-H. Hassenfratz, (1755-1827), inventor of a system of chemical symbols, and a militant revolutionary.

15 Emmanuel Grison, Du Faubourg Montmartre au Corps des Mines, l'étonnant parcours du républicain Jean-Henry Hassenfratz (1755-1827), Paris 1996, p. 105

16 J. Finnan, History of naval architecture, op. cit., p. 97.

17 AN: T/591, /4 and 5 he not only sent his agents abroad to do business, but he also provided technical teams. By 1785, they were demonstrating their bolts at Rochefort, where the copper bolts proved to be harder than the French iron ones and the French navy was importing British coppering materials in 1787. For copper, the equivalent of the Le Creusot works was at Romilly in Normandy, built on the British pattern, with English plant managers and a large cohort of English workers. ${ }^{18}$

\section{De Saudray}

Charles de Saudray, born in Paris in 1740, served in the army, where he acquired engineering and cartographical skills. In 1775, he became secretary to the French ambassador in London; he proceeded to take a very close interest in industrial developments in Birmingham and the expansion and mechanisation of the trades in light metal goods. D. P White has commented that nearly every year brought a new patent. ${ }^{19}$ De Saudray realised that there were so many different skills involved that their transfer to France would involve the recruitment of a large number of men with expertise in the various crafts.

In England, in the employ of the French foreign office, he achieved an ambition to acquire knowledge of a water-powered drive system to operate many processes at once in metal-working - "the driving of rolls for plating silver on copper, the mechanical polishing of metals, and particularly ornamental articles of polished steel (this being a Birmingham product highly fashionable in France) boring and stamping out machines, etc." ${ }^{20}$. The output was remarkable. Boulton produced eighty tons of buttons in 1798, ${ }^{21}$ and the 'number of substances of which they are made is almost inconceivable, and each requires a distinct set of manipulation. Amongst them are gold, silver, plated copper, white metal, mother of pearl, ivory, bone, horn, tortoise-shell, jet cannel, coal, paper, leather and a thousand others'.

De Saudray's access to knowledge of the machine was achieved at the works of Matthew Boulton, most famous of Birmingham's hardware manufacturers. Boulton had continued to produce ornamental hardware including ormoulu and silver plate but, in 1774, had brought James

18 AN: F/12/2222 and Guy Richard, "Les fonderies de Romilly sur Andelle", Actes du $88^{e}$ Congrès national des sociétés savantes, 1963, Section d'histoire moderne et contemporaine, Paris, 1964, pp. 451-467.

19 D. P. White, "The Birmingham button industry", Postmediaeval archaeology, 11, 1977, p. 76.

20 John R. Harris, "French industrial espionage in $18^{\text {th }}$ century Britain: two engineers', SHOT Conference, Sacramento, October 1989, p. 3.

21 Birmingham City Archives: Boulton and Watt Records, Box 37. 


\section{Examples of industrial and military technology transfer in the eighteenth century}

Watt to Birmingham for what was to be the celebrated steam engine partnership. De Saudray's espionage was most deliberate because "over the door of Sieur Boulton is written in gold letters approximately these words, 'entry to these works forbidden to all persons whatsoever, because of the problems which have already arisen from it' ... I did enter taking the greatest precautions; two hours after I made my drawings I was denounced to the English government, two of my workers were arrested and 24 hours later I would have been myself, if I had not fled England to avoid it".22

\section{Le Turc}

Le Turc, born in Lille in 1748, was a successful civil engineer much interested in framework knitting machines still based on an English $\mathrm{XV} \mathrm{I}^{\mathrm{h}}$ century invention. Le Turc was sued for debt, and fled to Britain where he travelled considerably, claiming to have visited a hundred towns. ${ }^{23}$ By 1785 he had begun to carry out intelligence work in England for the French government, probably starting when he took to France an advanced stocking loom for a French industrialist. A code was built up for Le Turc to use in correspondence, he took the name of Johnson and the street number of his house went into the code ${ }^{24}$. He insisted that he should obtain not only the English machines wanted by the Bureau of Commerce, but also, workmen capable of using them.

In England, Le Turc wrote that he "saw with dismay that a revolution in the mechanical arts, the real precursor, the true and principal cause of political revolutions, was developing in a manner frightening to the whole of Europe and particularly to France, which would receive the severest blow from it". ${ }^{25}$ He therefore, set about building up a collection of models and drawings of English equipment, industrial products and consumer goods. He also sent specimens to France; boxes with machine parts were filled up with earthenware to deceive the customs and sometimes bribes were used to get the goods through.

Perhaps Le Turc's major coup was in the area of military-industrial espionage, in connection with the Portsmouth system for the specialised and machineintensive production of naval pulley blocks, developed by the Taylor family from Southampton. ${ }^{26}$ The French

22 AN: F/12/1316, Mémoire de Charles de Saudray 23 John R. Harris, Industrial espionage and technology transfer. Britain and France in the XVIIIth century, Aldershot, Ashgate, 1998, pp. 448-452.

24 AN: F/12/677C.

25 lbid.

26 C. Cooper, "The Portsmouth system of manufacture", Technology and culture, 25, .2, 1984, pp. 182-225, cf. p. 186. navy quickly became aware of the superiority of these methods and, of course, wished to obtain them. ${ }^{27}$ In fact, they were at this time sending orders for pulleys to the Taylors. ${ }^{28}$ The system involved the use of circular saws for rough shaping the block, frames for boring devices and mechanisms for advancing them, and the use of specialised lathes for turning the iron or lignum vitae pins on which the pulleys, themselves of lignum vitae, rotated. Blocks of half the normal size could be used, an important point when a warship would take over a thousand. ${ }^{29}$ The French navy decided to try to set up production and asked Le Turc to obtain the necessary workmen, who were duly recruited. They set up at Brest a set of workshops for the Taylor system, which seem to have been completely satisfactory with a remarkably smooth transfer of technology.

\section{Scholarly visitors and the École des ponts et chaussées}

In the 1780s, a new type of observer was coming to Britain, notably from the Paris École des ponts et chaussées, where reports of these visits were collected and preserved. Interestingly, they are not all by "ponts et chaussées" engineers and it remains to determine the reasons for their presence in the library of that prestigious school. Were some of these engineers spying for France and who was behind this? It must, of course, be stressed that the main purpose for most of them was study and observation, but the fact remains that their reports could be very useful to an enemy of England. Two of them, Forfait and Lescallier were from the French navy and they produced a lengthy and thorough report of their findings.

In 1774, there was a new departure for the École des ponts et chaussées, the sending of one student "each year ... to a foreign country to acquire the new knowledge relative to the state of his destination. He will produce scale drawings of the main bridges, locks and machines and other most interesting things he may encounter during his journey, and these designs or a copy, as well as the relevant reports, will be deposited at the school to serve for the instruction of the students".30 1783 marked the end of the American War of Independence and the beginning of a brief period of peace between France and England. This meant that the successful students could visit the old historical enemy and see for themselves England's rapid progress in the sphere of industrialisation.

27 Archives du service historique de la marine [hereafter ASHM] : B'87, paper of 23 February 1778.

28 ASHM: B3 778, 788

29 C. Cooper, "The Portsmouth system", op. cit., p. 186.

30 André Brunot and Roger Coquand, Le Corps des ponts et chaussées, Paris, CNRS, 1982, p. 45-62. 
Similarly, English travellers could go to France and it is recorded, for example, that in 1788 and 1799 Arthur Young commented on the magnificence of what he had seen in France. He was much impressed with the development of Cherbourg and the quality of the roads.

So, a new type of Frenchman was coming to Britain; these were not industrialists bent on gaining the secrets of her success and using them to their own ends, but servants of the state, ostensibly on educational visits. Their reports provide details of what impressed them and their comments also give clues as to the usefulness to the French state of their accounts. Despite the temporary and uneasy state of peace, what could be potentially more useful to France than detailed drawings of bridges, ports, arsenals and the road network? Among the early visitors were Perronet, Lesage, Prony, Cachin, Forfait and Lescallier whose reports were duly deposited, in manuscript, in the library of the École des ponts et chaussées.

\section{Pierre-Charles Lesage (1740-1810)}

Lesage made visits to England in 1784 and 1785 when he was a qualified engineer. Originally employed as a draughtsman in the corps of military engineers, the "génie militaire", he became a "ponts et chaussées" engineer in 1776, having entered the school at the age of 34 when Perronet was director. Lesage became deputy director in 1794, was responsible for many improvements in the teaching and left a valuable collection of books and manuscripts for the students who came after him, including his reports on England. Of particular interest in the reports, dated September 1784 - January 1785, are the political and economic comparisons between France and England and an interest in military developments. It is apparent that, in 1801, Lesage was carefully following British parliamentary debates and studying details of shipping. ${ }^{31}$ This, combined with his attitude to Britain and his "patriotism", lends particular significance to his visits and comments, and his interest extended to the collection of militarily valuable reports by other visitors. Lesage's account ${ }^{32}$ begins with an "Idée génerale sur l'Angleterre", and it is here that he subsequently added marginal notes on British shipping. He expressed admiration for the state of British agriculture, noting that "this country produces

31 École nationale des ponts et chaussées [hereafter ENPC]: ms. 1968. The original French of sections of this report is reproduced verbatim in Margaret Bradley, "Engineers as Military Spies? French Engineers Come to Britain 1780-1790", Annals of science, 49, 1992, pp. 137-161.

32 ENPC: ms. 48. P-C. Lesage, Recueil de divers mémoires extraits de la Bibliothèque impériale des ponts et chaussées, 2 vols., Paris, 1810. all that France can produce, except for wine, oil and silk". He commented on commercial practices and the favouring over customs duty of certain countries, for instance, Portugal, whose products got off lightly compared with the heavily surcharged French goods. However, as a civil engineer, he concentrated on roads and highways. He studied the quality of the ground and abandoned routes, which were being restored. "Metalled with crushed flint, they are good and well-maintained", but there were not many, since "the sea and the internal waterways are adequate for all types of transport". On the other hand, "the Portsmouth and Dover-London roads are wide and well kept". He stated that "there are absolutely no roads in England but they are metalled or gravelled".

Portsmouth impressed Lesage particularly; he described it with details of the building materials used, bricks and Portland stone, and the street lighting. The surrounding roads he describes as "superb" and, with his engineer's eye, he noted varying widths and the way in which construction problems had been overcome. He recognised the importance of the PortsmouthLondon link as "very busy, especially with Royal Naval officers", and this led him to study the regulations and weighbridges. The structure of these he observed closely, as well as the dimensions of wheels and axles. Fine, detailed drawings accompanied his report. He took advantage of an opportunity to visit Coalbrookdale, again describing in detail what he saw there. Although his main preoccupation was with bridges and highways, he took careful note of anything useful mechanically, especially "a machine which I saw in Liverpool for unloading ships". Once again, he provided drawings and details, maintaining that "this machine is most ingenious and is used in several English ports ... its main aim is economy in the number of men employed in this type of work and also in time".

Lesage included accounts of London, various bridges, the old port of London, roads like London-Dover and Shrewsbury-London, toll regulations, machines for unloading ships and a full description of Portsmouth. The 80 drawings were also reproduced, including those of Plymouth and other English ports. His accounts of building materials, bridges and machines must have been useful additions to the store of knowledge at the École des ponts et chaussées. The published report, complete with uncorrected inaccuracies such as the rivers Solvay and Tuwed, seems innocent enough, but does not include the marginal notes of particular significance subsequently added by Lesage to another copy of his manuscript. ${ }^{33}$ They are as follows:

33 ENPC: ms 1968. 


\section{Examples of industrial and military technology transfer in the eighteenth century}

“Number of ships employed in trade

$1793 \ldots 16,000$ and 121,425 sailors

$1801 \ldots 18,898$ and 143,000 sailors

English statistics from 1790 to $1801^{\prime \prime}$.

He also noted imports and exports of, for example, manufactured articles, population statistics of England, Ireland, Scotland and Wales and, the following year 1802, from the Journal of Debates, the strength of the English Navy: "196 line vessels, 2550 - cannon ships, 218 frigates, 220 small warships". It is possible only to speculate on the reasons for these additions.

\section{Scholarly visits}

Prony was one of the first professors at the École polytechnique from its inception and was to become director of the École des ponts et chaussées in 1799. He was responsible for the training of some of France's finest engineers. ${ }^{34}$ In 1785, he went to England ${ }^{35}$ and attended at the completion of operations to link the Paris and Greenwich meridians. The point at issue was the relative positions of the Paris and Greenwich observatories and there was a difference of opinion between French and British astronomers. A commentator has observed that "the fact that such a matter could generate an international debate at all illustrates how the scientific community in eighteenth-century Europe maintained close contact across international frontiers". ${ }^{36}$

As a result of his visit, Prony translated from the English "Description of operations carried out in England to determine the respective positions of the Greenwich and Paris observatories", publishing this in 1791. He also translated General Roy's "Account of the methods employed for determining the measurement of the base of Hounslow Heath", an operation completed in 1784. ${ }^{37}$ His interest in England continued and when, in 1792, he became director of the Bureau du Cadastre, a cadastral survey on the lines of the British Board of Longitude, he sought inspiration in Adam Smith's An Inquiry into the Nature and Causes of the Wealth of Nations to create great mathematical tables "as pins are produced". With a large team of previously unemployed workers, he instituted tasks on the assembly-line principle and, in 1794, the distinguished mathematician Lalande reported that the Bureau had been producing 600 results a day.

34 M. Bradley, A career, op. cit.

35 P-C. Lesage, Notice pour servir à l'éloge de M. Perronet, Paris, 1805. 36 W. A. Seymour, A history of the ordnance survey, Folkstone, 1980, pp. 13-14

37 Gaspard de Prony, Description des moyens pour mesurer la base de Hounslow Heath, (translated from General Roy's account in the Philosophical Transactions), Paris, 1787.
Joseph Cachin was a product of the Benedictine Collège de Sorèze, where the various sciences constituted an important part of the curriculum and were taught in French. In 1780, he graduated from the École des ponts et chaussées and went to study naval engineering in America and England. He visited England in 1785 and produced a fine report ${ }^{38}$ of all that he had seen. His interests were broad and he studied the history of the places he went to. He was much impressed by "Dr Halley's diving-bell", 39 and told the story, in his report, of Charles Spalding who lost a ship near Sunderland in 1775. Spalding used a diving-bell to locate it and reported the results of his experiments to the Royal Society of London. Cachin visited lighthouses, lime kilns, the Portland quarries, Greenwich Hospital and the Monument. He studied the loading cranes on the Bridgewater Canal, where a horizontal cast-iron crane greatly impressed him. He examined and commented on building materials, concluding that red brick contained a lot of sand and that pure clay was the best material. He went to Chatham, Sheerness, Liverpool, Bristol and Portsmouth, a similar journey, in fact, to the one that Charles Dupin ${ }^{40}$ would make some thirty years later after events which were to shake Europe. Of Liverpool, he said that:

"the port is situated 182 miles from London on the bay of the St. George Canal ... and apart from the capital, may be considered to be the most thriving in England. Although the bay providing entry to this port is obstructed by changing sandbanks and consequently dangerous, and its situation does not seem favourable, nevertheless trade in Liverpool is prodigious and highly successful. It is a general storehouse of all sorts of foreign produce imported with the greatest of ease via the newly built canals coming to this port and from which the manufacturing products of Lancashire, Cheshire, Staffordshire, etc. are exported. It is also the most frequently used passage from England to Ireland. The largest ships arrive here all the time with their entire cargo right up to the docks; they are kept afloat and sheltered from the wind". ${ }^{41}$

\section{ENPC: ms. 87.}

39 Edmund Halley (1656-1742). In 1686, he demonstrated the law connecting elevation in the atmosphere with its density and, consequently, with barometrical readings. He materially improved diving apparatus and himself, made a descent in a diving-bell. In 1713, he was secretary to the Royal Society, and in 1729, Astronomer Royal.

40 Margaret Bradley and Fernand Perrin, "Charles Dupin's study visits to the British Isles, 1816-1824", Technology and culture, 32, 1, 1991, pp. 47-68.

41 ENPC : ms. 87. 
With drawings, he showed how areas of the port communicated with the docks so that 200 vessels could come and go by different ways. Cachin continued,

"Gosport, situated to the west of the entry to Portsmouth Harbour in the county of Hampshire is a very commercial town, principally in wartime. It is usually occupied by people involved in the service of the navy. There is a fine hospital for sick and wounded sailors; the entry to the harbour is protected by several fortresses, notably the platform of this hospital which consists of twenty cannons at waterlevel ... Portsmouth, separated from Gosport by a small stretch of sea, is situated on an island called Portsea, some 14 miles in circumference and linked to terra firma by a bridge ... This port is considered to be the key to England; since the last war, the town has been covered from citadel to shipyards (including the whole of its length on the land side) by a front of fortifications... The seaward side is defended by the citadel, towards the south, the town's artillery, the fort, the cannon wharf and a chain lying at the bottom of the mouth of the harbour ... to intercept the passage of enemy vessels, and a fantastic number of forts and batteries situated on the Hampshire coast ..."

The usefulness to a potential enemy of Cachin's report is apparent. He proceeded on a successful career path and was sent, in 1792, to Cherbourg, but the momentous political events of that year interrupted his service. He returned in 1805 to work on the foundations of the port, which had been completely destroyed by the British in 1758. He became Inspecteur général des ponts et chaussées, a member of the Conseil général des ponts et chaussées and was given the title of baron in 1813. It was his nephew, Batailler (1849) who took up the story subsequently, after Cachin's death, and explained the background to his work. ${ }^{42}$ He returned to the story of the diving-bell and the usefulness to the French of that invention:

"The English Doctor Halley is reputed to be the first to have recognised the possibility of existing under water, diving in an inverted vessel in the form of a bell, capable of retaining sufficient air for the diver to be able to breathe (p. 9). This physicist built a bell of $1.62 \mathrm{~m}$ in diameter at its base, surmounted with a convex glass in which he descended in the open sea to considerable depths without mishap, but he

42 A. P. E. Batailler, Description générale des travaux exécutés à Cherbourg pendant le Consulat et l'Empire ... d'après les projets ... de feu J.M.F. Cachin, 1848, Paris 1849. did not live long enough to perfect his ideas. After him, an Edinburgh amateur, Charles Spalding, who had lost his ships, wanted to use Dr Halley's bell to find his cargo".

The experiment failed but produced some interesting findings and in his account of his experiments to the Royal Society of London in 1775, he explained that he had been able to stay under water for periods of three hours, and at great depths, on several occasions. According to Batailler, this invention remained almost ignored or, at least, its potential in application went long unrecognised, but English engineers used it for the quay wall in Plymouth and, in 1817, it was used in Cherbourg. Batailler commented on the work there, "The bell ... has been used frequently since then and without any problems. With the aid of this machine, divers visit with ease, the depths of the channel and harbour entrance to a depth of 12 to 15 metres, regardless of tides" (p. 12). It had thus been possible to clear the harbour of vast amounts of debris, including the rudder of the ship Courageux and a case of rifles lost there for many years, which had long been sought by the usual means. So one result of Cachin's visit to England was that the French were able to repair what the British had destroyed. His report remained at the École des ponts et chaussées, full of useful information, or intelligence for the state.

\section{Forfait (1752-1807) and Lescallier (1743-1822)}

These two agents of the French navy went to England in 1789, producing their report the following year at a time of revolutionary developments in France. This is the most comprehensive and significant of the collection. Written by Lescallier, it was annotated by Forfait who was, apparently, ill for much of their visit. This report, Observations sur la marine anglaise is a comprehensive commentary on their findings. ${ }^{43}$

What is particularly important about these two is their concentration on the British navy. On activities at the Chatham dockyard, Cordingly ${ }^{44}$ has commented, that "a French spy surveying the scene from the tower of Frindsbury church would have gained a great deal of information about the strength of the British navy at this time" [1787-1790]. It was during this period that Forfait and Lescallier examined and observed everything as thoroughly as possible, making comparisons with France and recommendations for changes in French practice. If

43 For the complete report, see M. Bradley, Daniel Lescallier, op. cit., ASHM: ms CC7 1559: D. Lescallier, Observations sur I'Etat des Services, 30 June 1819.

44 D. Cordingly, Billy Ruffian, op. cit., p. 39. 
France were to compete with Britain, it was vital to improve her ships. The two travellers attributed much of Britain's superiority to the quality of her oak; coal was plentiful in Britain, so young oaks were not cut as they were in France. The authors urged the French government to research the question of coal - a sore point when France was struggling to develop coal-based technology. ${ }^{45}$

They also claimed that British tar, extracted from coal was of better quality than the French. Britain, in fact was obliged to import wood and France was richer in long straight timber; oak could be imported from Northern Germany. Forfait and Lescallier proposed the use of imported wood for the submerged sections of the ship and for the rigging, with French oak for brushing and reinforcing. They studied the treatment and cutting of wood, finding that the British methods were much more economical. They were much impressed by the pulleys produced by Garnett \& Co. with their reduced friction, and they described the manufacturing of rope and rigging which they considered to be of superb quality. They commented on the considerable economies resulting from tenders and competition in the supply system. They also noted the administration of the British navy and felt that, in France, it was essential to simplify accounting, to clarify areas of responsibility, "to get rid of superfluous personnel and to have a ruling whereby state funds would be in the hands of educated and thoroughly reliable people".

\section{The significance of Lesage's collection}

These were the reports carefully assembled and kept by Lesage. All the engineers mentioned here seem to have had a good command of the English language. How sinister were their motives? Cachin, for instance, produced detailed drawings of Britain's coastal fortifications. Forfait and Lescallier brought back to France materials to be tested for use by the French navy. ${ }^{46}$ Why was Lesage collecting all this material? He emerges as a very significant figure. In his manuscript Journal et observations sur l'Angleterre et principalement sur les grandes routes, his attitude is well illustrated. He wrote:

"It is to England and particularly the City of London that we owe the fortunate idea of establishing a steam pump [pompe a feu] in Paris. We have to confess that it was an Englishman who in the month of April 1778, came here with the proposal of an abundant supply

45 John R. Harris, "Industrie et technologies au XVIII' siècle (1), la Grande Bretagne et la France », Analyse des systèmes, 1982, 3, pp. 2-23.

46 See, for example, Section 23 of their report in M. Bradley, Daniel Lescallier, op. cit. of all necessary water to our city (as in London), by means of steam pumps, and he obtained exclusive rights for this. If we failed to have the original idea we were, at least, not lacking in patriotism, and some citizens whose memory will one day be held dear by our descendants, decided to strip the foreigner of this honour. They formed a society, acquired from England this humiliating privilege and, assisted by the talents of the Périer brothers, they took the risk of spending 2,000,000 [livres?] above all for the purchase and importation of all pipes and cylinders necessary which they decided to acquire from England, in the absence of sufficiently intelligent French workers or enough money to undertake the production". ${ }^{47}$

Such was Lesage's attitude. The Englishman in question was Joseph Alcock who visited England from France in 1777. On his return, he drew to the attention of the French government the Boulton and Watt engine, as he thought that Boulton might be able to erect one or more in France. ${ }^{48}$ Alcock's report prompted two prestigious members of the Académie des sciences, Macquer ${ }^{49}$ and Montigny, who were frequently requested to submit technological reports to the government, to comment on the project. They were most interested in the idea of steam as compared with an atmospheric engine, and considered that one such should be installed for the Paris waterworks to replace the hydraulic pumps at Notre Dame. It was Alcock's initiative which presaged the Périer' Chaillot works with Watt engines installed, legitimately at first, but subsequently pirated..$^{50}$

\section{The French navy and espionage}

Forfait and Lescallier were far from being the first agents of the French Navy. ${ }^{51}$ In 1723, when Phélypeaux, Count of Maurepas became Minister for the French Navy, the fleet had dropped from over 140 ships to fewer than thirty. A new fleet was essential in view of the continued threat from Britain. Maurepas looked to the technical expertise of his erstwhile enemies Britain and the Netherlands and began a campaign of both operational and technical

47 M. Bradley, "Engineers as Military Spies?", op. cit. 48 J. R. Harris, "Michael Alcock", op. cit. 49 P. Macquer, chemist (1718-1784). For Montigny, see fn. 2. 50 AN: F/12/2205, J. Alcock to Tolozan, 10 January 1778.

51 More details are given in Larrie Ferreiro, "Spies versus prize: technology transfer between navies in the age of Trafalgar", in F. Fernando-Gonzàlez, L. D. Ferreiro and H. Nowacki eds., Technology of the ships of Trafalgar, Madrid, November 2005; M. Bradley, "Engineers as Military Spies?", op. cit.; id., "Bonaparte's plans to invade England in 1801: the fortunes of Pierre Forfait", Annals of science, 51, 1994, pp. 453-475 ; id., Daniel Lescallier, op. cit.. 
espionage, focusing on Britain. ${ }^{52}$ In particular, Maurepas sent two constructors and a botanist abroad in the 1730s, to report back on technological practices. They found it fairly easy to enter dockyards, and many people more than willing to speak with them and even provide them with ships' plans and materials. The first of these was the young constructor Julien Geslain, designer of Magnanime and Fidèle, who went to various dockyards in Britain from 1729 to 1732. In a 12-page report on Britain (July 1732), he claimed to have brought back plans of several vessels and included observations that were later incorporated into French naval ships, notably improved ventilation of the bottom frames to lessen deterioration.

In 1737, Blaise Ollivier described a visit to Britain and Holland. ${ }^{53}$ He made notes on almost everything he saw, including the putting of deck beams under tension during construction and filling in the spaces between frames with fir. He noted the practice of adding iron bracings for hull strength. According to his manuscript and correspondence, he copied or adapted many of these British and Dutch practices in his own design and building methods. Ollivier was one of the most skilled constructors in the French navy, and he trained many younger builders in the new school of construction, so that by the 1750 s these foreign practices had, effectively, become standard French technique.

In the same year, Duhamel du Monceau, went on a separate mission to Britain. He visited several ports and made full notes. He was to become Inspector General of the Navy and head of the École des ingénieursconstructeurs de la Marine. His colleague Ollivier taught naval construction at Duhamel's school in its earliest years. The Seven Years War from 1756 to1763 obliged France once again to rebuild her fleet. Britain was again targeted by French spies, but now the interest was in the technological innovations that Britain was developing during the Industrial Revolution. Almost immediately after the cessation of hostilities, and from 1764-1765, naval officer Fulque, Chevalier d'Oraison, visited six British dockyards. He reported on numerous developments, including a new type of chain pump for evacuating bilges. The most important point, however, was the use of copper plating to sheathe the hull to protect against teredo worms. In addition to the efficacy against worm damage, the Navy noted that the bottom

52 See especially the written descriptions of "Spying and its uses" in Historical French documents of the eighteenth century, 73, 1962 pp. 26-29, Maurepas Collection, Cornell University. 53 This report is transcribed, translated and extensively annotated by David H. Roberts in his reedition of Blaise Ollivier, Remarques sur la Marine des Anglois et Hollandois (1737), Nice, Éditions Ancre, 1992. stayed relatively free of barnacles and other fouling (copper is poisonous). As a result of d'Oraison's report, the first of this important innovation, the Minister of the Navy Choiseul requested that his embassy in London obtain as much information as possible on coppering. One of d'Oraison's fellow officers, the Comte de RosilyMesros, undertook to continue d'Oraison's work, and from 1775-1777 he travelled throughout Britain, gaining easy entry to dockyards. On one occasion, he managed to join a tour of the 64-gun HMS Aigle, led by an admiral who was its former commander. Rosily's main interests, however, were two innovations developed by Walter Taylor and William Cole, the first being the chain-pump originally described by d'Oraison, and the second being the Taylor and Cole pulley-blocks already mentioned. Rosily managed to arrange for Cole to come to France to have his machines tested, and to establish a factory in Brest. We have seen that France eventually set up a blockmaking factory in Lorient based on Taylor's principles, under the direction of Le Turc.

Copper sheathing was back on the scene when the Comte de Kersaint went to Britain in 1785. He had previously influenced Minister of the Navy Sartine to reexamine copper sheathing in 1778 and now the French navy redoubled its efforts to sheathe all its ships. Shortly after Kersaint's voyage, the navy placed major orders with the Romilly plant, which became the principal supplier to the French navy until the time of Trafalgar. ${ }^{54}$

So espionage benefited industry, while visits like those of Lesage and Cachin from 1785 to 1790, were intended to provide hard military intelligence as seen through the critical eyes of seasoned engineers. In particular, the 1789 mission of Forfait and Lescallier produced considerable information on coastal defences, harbours, fortifications and dockyards, as well as of the ships themselves. Forfait later served as counsellor to Napoleon, doing his best to persuade him to invade Britain, but hope of that was abandoned with the defeat of his combined fleet at Trafalgar.

These have been just a few examples of technology transfer, official or clandestine, but they are representative of a vast field of activity. Such action helped to accelerate the process of industrial developments in the countries of those involved, and the military intelligence would be vital in the event of war.

54 Sylviane Llinares, Marine, propulsion et technique : l'évolution du système technologique du navire de guerre français au XVIII siècle, Paris, Librairie de I'Inde, 1994, pp. 105-107, 130-135, 351-353; J. R. Harris, Industrial espionage, op. cit., pp. 263-283. 